\title{
LOGISTICS AND INTERNATIONAL TRADE DEVELOPMENT RELATIONSHIP: EVIDENCE OF EUROPEAN UNION MEMBER STATES
}

\author{
Alma Mačiulytė-Šniukiené $\dot{1}^{1}$ Aurelija Burinskiené \\ Department of Business Technologies and Entrepreneurship, Faculty of Business Management, \\ Vilnius Gediminas Technical University, Saulètekio al. 11, Vilnius, Lithuania \\ E-mails: 'alma.maciulyte-sniukiene@vgtu.lt (corresponding author); ${ }^{2}$ aurelija.burinskiene@vgtu.lt
}

Received 07 March 2020; accepted 05 May 2020

\begin{abstract}
International trade (IT) is recognised as one of the driving forces for business and the growth of countries' economic. The amount of IT flows is contributed by the "logistics revolution". According to the conceptual approach, the development of transportation modes, logistics infrastructure may facilitate international trade. However, it remains unclear whether logistic performance changes contribute to IT flows since the number of researches that examine the effect of logistic performance on IT is limited. So, this paper aims to determine whether the flows of IT are contingent on logistics performance. The research relies on panel data of 28 European Union (EU) Member States (MS) over 2007-2016. The results of our investigation confirmed that the changes of logistics performance positively related to IT flow of EU MS, but this impact differs across countries.
\end{abstract}

Keywords: logistics, logistics performance, logistics indicators, international trade, European Union.

JEL Classification: F140, O520, R400.

\section{Introduction}

Increasing respect for the development of international trade and logistics by policymakers has led to significant improvements in the dialogue between politicians and private sectors. They prioritize the facilitation of trade and transport. However, trade and logistics are economic sectors that contribute to national or sub-regional competitiveness. Various methods of analysis are required for a comprehensive multidimensional evaluation of trade logistics performance, which is essential for action plans and policies, such as changes in national regulation and investments to infrastructure, which interconnects corridors and nodes. This also represents elements promoting logistics efficiency and barriers which hinder operations. Aiming to evaluate logistics efficiency and it changes scientists and practitioners creates and devepopes various indexes. One of the most common indexes Logistic performance index (LPI) created by World bank in colloboraion with Turku School of Economics, University of Turcu (Arvis et al., 2018). LPI scores are provided in World Bank data basis.

According to World Bank (n.d.) data, the performance of logistics in most of EU countries is improving, as well the flows of international trade are rising. However, it remains unclear whether overall logistic performance influences interna- tional trade flows positively and significantly since research that examine the effect of logistic performance on international trade are limited. The analysis of previous studies (Lakshmanan et al., 2001; Limao \& Venables, 2001; Devlin \& Yee, 2005; Memedovic et al., 2008; Hausman et al., 2013) reveals that logistics efficiency may contribute to international trade, as well as can be treated as the conditional factor for export impact on economic growth (Tang \& Abosedra, 2019). However, those studies cover only a few aspects of logistics. Given this fact, it is appropriate to use a logistic performance index that includes many indicators of logistic performance and represents a logistic situation in a more sophisticated way for further investigation. So, this paper aims to examine whether the flows of IT are contingent on logistics performance. Moreover, the logistics performance is indicator of international trade development. The size of international trade governs the size of production and distribution and influences the economy in general.

The rest of the paper is organized as follows: Section 2 presents a literature review on the evaluation of logistics performance, logistic performance index structure, and results of previous investigations. Section 3 describes the research data and the research model. Section 4 provides an analysis of international trade and logistic perfor- 
mance. Section 5 presents and discusses the results of the investigation of the logistic performance changes impact on international trade. The last section concludes the paper.

\section{Literature review}

\subsection{The evaluation of logistics performance}

The performance of logistics in the country is an essential aspect representing the ability to provide logistics activities and contributing to domestic and international trade facilitation (Anderson \& Villa, 2015). Logistics activities typically include freight delivery, payment and custom clearance formalities, etc., which makes the complex sequence of concerted practices.

The characteristics of excellent logistics reflect the movement of goods within the country in the frame of time, speed, and costs. It also shows favourable conditions for international trade within the country (Havenga, 2011; Havenga et al., 2016).

The continuing analysis of logistics performance focuses on costs and gains of trade facilitation (Banomyong et al., 2008; Hausman et al., 2005; Hoekman \& Nicita, 2011; Rodrigues et al., 2005), or inherently tend to valuate challenges (Chow et al., 2005; Gupta et al., 2011; Wang et al., 2014).

Besides, for the evaluation of complex trade logistics, the performance index (LPI) is used. LPI also shows the trends over time. Performance is rated on a 5 points scale, and the LPI is constructed as a weighted average of six logistics activities, which are counted as equally crucial during index calculation. The LPI also includes local performance indicators that are not evident in the overall country score. It also supplements specific aspects of countries, including imports and exports, delivery times, supply costs, customs formalities and the percentage of physically checked shipments (Mariano et al., 2017).

The LPI is used in 160 countries and allows a comparison that is consistent with the rating rather than amelioration of actual LPI values. The score of LPI is highly dependent on the incomes and geographic location of the country. In general, among all countries, the top 10 countries have a highincome level (like the US, Sweden, Austria, etc.); usually, these countries play a significant role in the world supply chain and have well-established logistics. There are several middle-income countries, which have high productivity score because their economies are booming (Çemberci et al., 2015). Despite that, several countries have pub- lished specific LPI rating targets in their plans for strategic development. To LPI scores, these countries are undertaking essential projects in many areas (Ojala \& Celebi, 2015).

For indicate future LPI score level, various methods could be used, like deterministic prediction models.

Deterministic prediction models have mainly used for observation the impact of logistics on improving trade or the general economy. The main disadvantages of such models are that they provide just forecast, which is not considering systemic changes (Roy et al., 2018).

Especially for long-term strategic planning, techniques of foresight, back-casting and scenario analysis are available, which estimate very uncertain future conditions useful for decision making (Tietje, 2005).

Back-casting is a way to explore long-term scenarios investigation focusing on the achievment oriented to desired future. First, the desired vision for the future is created. After the researchers look back, aiming to indicate how this future can be gained. The approach is the opposite of forecasting, which suggests the future by assuming the available conditions. Although, it is not easy to observe, the inter-relation between variables by applying the back-casting technique (Wangel, 2011).

On the other hand, scenario analysis is the method used for planning. It encourages the consequences of decisions and actions. So, scenario analysis should consist of several very different but for practical scenarios as it guides decision-makers towards different combinations, which are not necessarily most acceptable. Also, it offers a choice of significantly different, sequential, and small numbers of practical scenarios. The effectiveness of strategies is identified with a unique approach. This approach could involve correlation analysis, which considers the different combinatorial effects of variables and thus uses information that overlooks traditional linear correlation methods (Kabak et al., 2018).

Coming back to LPI evaluation, the World Bank and Turku School of Economics, University of Turcu, provided an assessment of logistics performance in index form (LPI) (Arvis et al., 2018). Authors Mitra et al. (2018) suggested a two-step methodological framework for delivering extend insights obtaining LPI. The two-step methodological framework has linked important macroeconomic variables to LPI. Although Martí, Martín, and Puertas (2017) proposed a method that uses DEA as a multi-criteria tool for decision making. DEA is 
an alternative method to evaluate LPI. Also, authors Rezaei, van Roekel, and Tavasszy (2018) proposed the best worst way and assigned different weights to index related logistics activities based on created economic value. Neverthless, the most common is index developed by World bank in collaboration with Turku School of Economics, University of Turku (Arvis et al., 2018). Many authors use this index in their research (Puertas et al., 2014; D'Aleo \& Sergi, 2017; Sharipbekova \& Raimbekov, 2018; Tang \& Abosedra, 2019, etc.).

\subsection{The core elements of LPI}

Aiming to provide a wealth of research on various important factors of trade logistics, this section examines the literature covering logistics results or related economic used components with logistics efficiency.

Factors determining the effectiveness of LPI and customs components involve predictable and straightforward aspects. There are many studies regarding customs which is an essential factor but relatively less important than logistics and transport efficiency. In developed countries, small customs can enhance the effectiveness of overall logistics systems. In the literature, customs are treated as essential functioning structures in facilitating trade.

The infrastructure is one of the trade factors. To transport policy, the in terms of construction and maintenance costs also creates excellent benefits. Most of the studies link transport infrastructure to economic and sales growth by identifying logistics services as linking critical activities. These effects are different for booming midincome and stable high-income countries.

The arrangement of shipments measures how easy it is to organize transfers and what is the competitiveness of shipping prices (Puertas et al., 2014).

The quality of logistics services stands for the logistics ability of the country to reach competitiveness and prosperity. The high quality of logistics services has a positive effect on economics. Also, transport policy could help to achieve the quality of logistics services through regulatory mechanisms towards the transport sector or traffic management (Civelek et al., 2015). For example, the policy of "Green freight Europe" is oriented to the minimization of environmental risks related to the transport sector (Zaman \& Shamsuddin, 2017).

Tracking and tracing help to identify the position of freight, which leads to supply chain efficiency, but on the other hand, it increases the con- sumption of energy, which is retrieved from mined fuel.

Timeliness means that shipments are delivered to the right place at the exact time; in particular, it reduces the number of days in transit. The reduction of $1 \%$ of the time needed for formalities in customs and port of the exporting country, contribute to the increase of flows in bilateral trade.

In 2014, The World Bank highlighted significant differences in delivering trade logistics reform dependent on different sizes of investments and the complexity of these reforms. Various strategies have been discussed further to improve logistics performance across countries. Countries associated with low-income levels could improve infrastructure and customs. Countries, where the income level is in the middle, could focus on the quality of logistics services, in particular, on freight delivery and warehousing. And countries with high-income level demand could concentrate on logistics, which is friendly to the environment (Lai \& Wong, 2012).

This inspired authors to deliver research evaluating logistics performance from the perspective of the EU.

\subsection{Impact of logistics performance on interna- tional trade}

Logistics facilitate import and export activities by reducing costs, time and complexity. Numerous empirical studies have investigated the impact of logistics performance on trade volumes. Hausman et al. (2013) have analysed costs for crossing the borders to bring goods from one country to another and the impact of logistics efficiency on bilateral trade. They have figured out that the distance and goods transportation costs, as well as applicable duties and taxes, are influencing the trade volume between partners.

Limao and Venables (2001) find a strong statistical relationship between transport costs and the flows of international trade. These authors find an evident link between the quality of the infrastructure and the costs of transport, which means that investments in infrastructure are important for export growth.

Memedovic et al. (2008) reviewed critical developments in global logistics for the past 20 years. They concluded that today's global supply chains require advanced logistics services, including innovations in freight deliveries and information technologies supporting physical distribution and material handling.

Tang and Abosedra (2019) examined the relationship between logistics performance, export and economic growth and concluded that logistic per- 
formance is a conditional factor for positive export effects on economic growth.

Despite that, logistics services facilitate international trade and play a significant role in the development of the local economy. The performance of logistics services can play a vital role in international trade. In such a case, the poor logistics infrastructure and logistics services can mean the main barriers to international trade integration (Devlin \& Yee, 2005). In contrast, improved the performance of logistics in line with the economic environment can enlarge the volume of trade that also influences the size of distribution and production (Lakshmanan et al., 2001).

By summarizing all the above stated, it is vital to evaluate logistics performance, including as many components as possible (core components) as they have a significant impact on the level of international trade. Aiming to determine the strength of the impact of logistic performance on international trade empirical research is provided.

\section{Data and methodology}

The research is based on the data collected for 28 countries of EU MS for the period 2007-2018. Table 1 gives the notation and description of the indicators. These indicators are used for the study as dependent, independent and control variables.

Table 1. Notation and description indicators taken for the investigation (source: composed by the authors)

\begin{tabular}{|l|l|l|l|}
\hline \multicolumn{1}{|c|}{ Indicator } & $\begin{array}{l}\text { Notation } \\
\text { \& units }\end{array}$ & $\begin{array}{c}\text { Data } \\
\text { source }\end{array}$ & Explanation \\
\hline \multicolumn{3}{|c|}{ Dependent variable } \\
\hline $\begin{array}{l}\text { International } \\
\text { trade \% } \\
\text { GDP }\end{array}$ & $\begin{array}{l}\text { ITP_gdp } \\
(\%)\end{array}$ & $\begin{array}{l}\text { World } \\
\text { bank }\end{array}$ & $\begin{array}{l}\text { Export+import } \\
\text { goods and ser- } \\
\text { vices as a per- } \\
\text { centage of GDP }\end{array}$ \\
\hline $\begin{array}{l}\text { Logistics } \\
\text { performance } \\
\text { index }\end{array}$ & $\begin{array}{l}\text { LPI } \\
\text { (score) }\end{array}$ & $\begin{array}{l}\text { World } \\
\text { bank }\end{array}$ & $\begin{array}{l}\text { See 2.2 subsec- } \\
\text { tion of the article }\end{array}$ \\
\hline \multicolumn{3}{|c|}{ Control variables } \\
\hline $\begin{array}{l}\text { Gross capi- } \\
\text { tal for- } \\
\text { mation per } \\
\text { capita }\end{array}$ & $\begin{array}{l}\text { GCF_pc } \\
\text { (current } \\
\text { USD) }\end{array}$ & $\begin{array}{l}\text { World } \\
\text { bank }\end{array}$ & $\begin{array}{l}\text { The fixed assets } \\
\text { of the economy } \\
\text { plus net changes } \\
\text { in the level of } \\
\text { inventories }\end{array}$ \\
\hline $\begin{array}{l}\text { New busi- } \\
\text { ness density }\end{array}$ & $\begin{array}{l}\text { NBD } \\
\text { (units) }\end{array}$ & $\begin{array}{l}\text { World } \\
\text { bank }\end{array}$ & $\begin{array}{l}\text { New registrations } \\
\text { per 1000 people } \\
\text { ages 15-64 }\end{array}$ \\
\hline
\end{tabular}

International trade covers both export and import. In some studies, the authors used net export (export minus import) as an international trade indicator. Given that both export and import can positively influence countries' economy (Davidaviciene \& Maciulytė-Sniukienè, 2018), export and import are summed up and measured as a percentage of GDP in this study.

It should be noted that the World Bank (n.d.) provide LPI scores for the periods of 2007, 2010, 2012, 2014, 2016, and 2018. Herein, we are calculated the missing values by using the extrapolation method.

In the first stage of the study, we analyses international trade and logistics performance and its changes over the 2007-2018 period. This analysis reveals the trends of variations of both indicators and allows to make assumptions about the existence (non-existence) of links between them.

In the next stage of the study, we have ranked EU-28 MS according to the scores of LPI and amount of international trade in 2018 and calculated the difference between ranks to determine whether countries with an excellent logistical situation have flows of international trade.

In the last stage of this investigation, we assessed how change in logistics performance impacts the changes of the volume of international trade.

Panel data of all EU MS, except Luxembourg is used in the study. The Luxembourg is excluded from the sample due to the large gap from other countries. United Kingdom is included into the sample since, in the year of 2018 it was a member of EU.

The Fixed-Effect (FE) econometric model was developed for the evaluation of the LPI changes impact on international trade.

$$
\begin{array}{r}
\left.\operatorname{Ln}\left(I T \_g d p\right)_{(i, t)}=\alpha+\beta_{1} \ln (L P I)_{(i, t)}\right)+ \\
+\beta_{2} \ln \left(G C F_{p c} c_{(i, t)}\right)+\beta_{3} \ln \left(N B D_{(i, t)}\right)+u_{i, t},
\end{array}
$$

where:

- $\operatorname{Ln}(I T)_{(i, t)}$ - logarithmic dependent variable, international trade \% GDP, in country $i$ in year $t$;

- $\alpha$ constant;

- $\ln (L P I)_{(i, t)}$ - logarithmic independent variable, logistic performance index, in country $i$ in year $t$;

- $\ln \left(G C F \_p c\right)_{(i, t)}$ - logarithmic independent control variable, gross capital formation per capita, in country $i$ in year $t$;

- $\ln (N B D)_{(i, t)}$ - logarithmic independent control variable, new business density, in country $i$ in year $t$; 
- $u_{i, t}-$ random model error;

- $\beta_{1}, \beta_{2}, \beta_{3}, \beta_{4}$ elasticity coefficients, reflecting the impact of independed variables on the growth of international trade.

All variables will be logarithmic to obtain the coefficients of elasticity.

Table 2. Results of the international trade dynamic analysis in EU MS (source: authors calculations based on World Bank (n.d.) data)

\begin{tabular}{|c|c|c|c|}
\hline \multirow[t]{2}{*}{ Country } & \multicolumn{3}{|c|}{$\begin{array}{l}\text { International trade (\% of } \\
\text { GDP) }\end{array}$} \\
\hline & 2007 & 2018 & $\Delta$ \\
\hline Austria & 100.73 & 107.79 & 7.06 \\
\hline Belgium & 152.47 & 165.31 & 12.85 \\
\hline Bulgaria & 123.59 & 131.25 & 7.66 \\
\hline Cyprus & 111.27 & 145.35 & 34.07 \\
\hline Czech Republic & 130.37 & 150.39 & 20.02 \\
\hline Germany & 79.87 & 88.67 & 8.80 \\
\hline Denmark & 100.07 & 105.24 & 5.17 \\
\hline Spain & 57.75 & 67.52 & 9.77 \\
\hline Estonia & 134.01 & 145.00 & 10.99 \\
\hline Finland & 82.86 & 77.85 & -5.00 \\
\hline France & 56.42 & 63.45 & 7.03 \\
\hline United Kingdom & 52.46 & 61.78 & 9.32 \\
\hline Greece & 57.52 & 72.52 & 15.00 \\
\hline Croatia & 84.07 & 101.88 & 17.81 \\
\hline Hungary & 155.35 & 165.50 & 10.16 \\
\hline Ireland & 153.29 & 211.51 & 58.22 \\
\hline Italy & 55.06 & 60.41 & 5.35 \\
\hline Lithuania & 113.84 & 149.30 & 35.46 \\
\hline Luxembourg & 332.50 & 387.10 & 54.60 \\
\hline Latvia & 95.93 & 122.79 & 26.86 \\
\hline Malta & 258.51 & 268.85 & 10.34 \\
\hline Netherlands & 130.46 & 157.65 & 27.20 \\
\hline Poland & 80.66 & 107.74 & 27.08 \\
\hline Portugal & 69.95 & 86.96 & 17.01 \\
\hline Romania & 63.51 & 86.49 & 22.99 \\
\hline Slovak Republic & 166.33 & 190.16 & 23.83 \\
\hline Slovenia & 137.13 & 162.48 & 25.35 \\
\hline Sweden & 89.40 & 89.07 & -0.33 \\
\hline EU Average & 115.19 & 133.21 & 18.02 \\
\hline
\end{tabular}

\section{Analysis of the international trade and logistics performance in EU-28 MS}

Among many goals, each country aims to increase flows of export. According to export lead growth (ELG) theory, export is key factors of economic growth (Yang \& Wu, 2015; Ali \& Li, 2018; Abosedra \& Tang, 2019, etc.). However, proponents of the import lead growth (ILG) theory (Awokuse, 2008; Mahadevan \& Suardi, 2008; Palley, 2011, etc.) argues that the value of import are more significant for economic growth compering to export. The results of the previous empirical estimations reveal that both export and import can positively influence economic growth. Therefore, it is important to analyse the dynamic of combined export and import volumes.

To evaluate relations between the performance of logistics and international trade the analysis of IT dynamics is presented (see Table 2).

The analysis reveals that the value of international trade measured as \% of GDP increases in all EU member states except Finland and Sweden over the study period. The imports of products and services in Finland, increases by $8.81 \%$, but export decreases by $5.90 \%$, and this (including GDP increase by $8.08 \%$ ) led to the decrease of international trade \% of GDP. In Sweden, both volume of export and import increase over the period, but due to rapid GDP growth, IT \% of GDP indicator slightly decrease $(0.33 \%)$. The most significant increase is in Ireland (58.22\%) and Luxembourg (54.60). Lithuania takes third place undergrowth of the IT \% GDP $(35.46 \%)$. The smallest positive change of IT \% GDP is recorded in Denmark (5.17\%), Italy (5.36\%) and Denmark (5.17\%). Aiming to determine whether these changes are linked to the situation of logistics in particular country, the further analysis is carried and the change of the logistic performance index's is estimated (see Table 3).

As shown in Table 2, the improvment of logistics performance is evident in 20 out of $28 \mathrm{EU}$ MS. In 7 countries (such as Austria, Greece, Ireland, Latvia, Malta, Netherlands, and Sweden), LPI value decreased, and in the United Kingdom, logistics performance was stable. The most significant improvement of logistics performance was in the Czech Republic, where it bumped by 0.55 points, in Poland - by 0.50 points, and in Croatia by 0.39 points. Nevertheless, the leading countries in the frame of LPI are Germany, Sweden, and Belgium (see Table 4) and keep the stable positions from year 2007 to year 2018 . 
Aiming to determine, whether the countries which are leading in logistics are generate the most international trade flows, 28 EU member states are ranked according to LPI and IT \% of GDP in 2018. The analysis has revealed that the excellent logistic performance in the country is not necessarily means the intensive flows of international trade, except Romania, which position under both LPI and IT \% GDP is on the same stage (22).

Table 3. Results of the LPI dynamic analysis in EU MS (source: authors calculations based on World Bank (n.d.) data)

\begin{tabular}{|c|c|c|c|}
\hline \multirow{2}{*}{ Country } & \multicolumn{3}{|c|}{ LPI } \\
\hline & 2007 & 2018 & $\Delta$ \\
\hline Austria & 4.06 & 4.03 & -0.03 \\
\hline Belgium & 3.89 & 4.04 & 0.15 \\
\hline Bulgaria & 2.87 & 3.03 & 0.16 \\
\hline Cyprus & 2.92 & 3.15 & 0.23 \\
\hline Czech Republic & 3.13 & 3.68 & 0.55 \\
\hline Germany & 4.1 & 4.20 & 0.10 \\
\hline Denmark & 3.86 & 3.99 & 0.13 \\
\hline Spain & 3.52 & 3.83 & 0.31 \\
\hline Estonia & 2.95 & 3.31 & 0.36 \\
\hline Finland & 3.82 & 3.97 & 0.15 \\
\hline France & 3.76 & 3.84 & 0.08 \\
\hline United Kingdom & 3.99 & 3.99 & 0.00 \\
\hline Greece & 3.36 & 3.20 & -0.16 \\
\hline Croatia & 2.71 & 3.10 & 0.39 \\
\hline Hungary & 3.15 & 3.42 & 0.27 \\
\hline Ireland & 3.91 & 3.51 & -0.40 \\
\hline Italy & 3.58 & 3.74 & 0.16 \\
\hline Lithuania & 2.78 & 3.02 & 0.24 \\
\hline Luxembourg & 3.54 & 3.63 & 0.09 \\
\hline Latvia & 3.02 & 2.81 & -0.21 \\
\hline Malta & 2.82 & 2.81 & -0.01 \\
\hline Netherlands & 4.18 & 4.02 & -0.16 \\
\hline Poland & 3.04 & 3.54 & 0.50 \\
\hline Portugal & 3.38 & 3.64 & 0.26 \\
\hline Romania & 2.91 & 3.12 & 0.21 \\
\hline Slovak Republic & 2.92 & 3.03 & 0.11 \\
\hline Slovenia & 3.14 & 3.31 & 0.17 \\
\hline Sweden & 4.08 & 4.05 & -0.03 \\
\hline EU Average & 3.41 & 3.54 & 0.13 \\
\hline
\end{tabular}

Table 4. The ranking of EU-28 member states according to LPI and the volume of the international trade (source: authors calculations based on World Bank (n.d.) data)

\begin{tabular}{|l|c|c|c|c|c|}
\hline Country & LPI & $\begin{array}{c}\text { Rank } \\
\text { acc. } \\
\text { LPI }\end{array}$ & IT & $\begin{array}{c}\text { Rank } \\
\text { acc. } \\
\text { LPI }\end{array}$ & $\begin{array}{c}\text { Posit. } \\
\text { diff.* }\end{array}$ \\
\hline Austria & 4.03 & 4 & 107.79 & 15 & -11 \\
\hline Belgium & 4.04 & 3 & 165.31 & 6 & -3 \\
\hline Bulgaria & 3.03 & 24 & 131.25 & 13 & 11 \\
\hline Cyprus & 3.15 & 21 & 145.35 & 11 & 10 \\
\hline Czech Rep. & 3.68 & 12 & 150.39 & 9 & 3 \\
\hline Germany & 4.20 & 1 & 88.67 & 20 & -19 \\
\hline Denmark & 3.99 & 6 & 105.24 & 17 & -11 \\
\hline Spain & 3.83 & 10 & 67.52 & 25 & -15 \\
\hline Estonia & 3.31 & 19 & 145.00 & 12 & 7 \\
\hline Finland & 3.97 & 8 & 77.85 & 23 & -15 \\
\hline France & 3.84 & 9 & 63.45 & 26 & -17 \\
\hline UK & 3.99 & 7 & 61.78 & 27 & -20 \\
\hline Greece & 3.20 & 20 & 72.52 & 24 & -4 \\
\hline Croatia & 3.10 & 23 & 101.88 & 18 & 5 \\
\hline Hungary & 3.42 & 17 & 165.50 & 5 & 12 \\
\hline Ireland & 3.51 & 16 & 211.51 & 3 & 13 \\
\hline Italy & 3.74 & 11 & 60.41 & 28 & -17 \\
\hline Lithuania & 3.02 & 26 & 149.30 & 10 & 16 \\
\hline Luxembourg & 3.63 & 14 & 387.10 & 1 & 13 \\
\hline Latvia & 2.81 & 28 & 122.79 & 14 & 14 \\
\hline Malta & 2.81 & 27 & 268.85 & 2 & 25 \\
\hline Netherlands & 4.02 & 5 & 157.65 & 8 & -3 \\
\hline Poland & 3.54 & 15 & 107.74 & 16 & -1 \\
\hline Portugal & 3.64 & 13 & 86.96 & 21 & -8 \\
\hline Romania & 3.12 & 22 & 86.49 & 22 & 0 \\
\hline Slovak Rep. & 3.03 & 25 & 190.16 & 4 & 21 \\
\hline Slovenia & 3.31 & 19 & 162.48 & 7 & 12 \\
\hline Sweden & 4.05 & 2 & 89.07 & 19 & -17 \\
\hline
\end{tabular}

\section{Results of the estimation relationship between LPI and international trade, and discussion}

The panel data regression analysis, using the Fixed-effects model, was taken to estimate logistics performance changes impact on volume change of international trade (see Table 5).

The results of estimation show a positive but not significant effect of changes of logistics performance on changes of volumes in EU MS international trade. Changes in gross capital formation (\% of GDP) influences international trade positively and significantly, but the impact is not essential. The flows of international trade are more depend- 
ent on new business density. An increase in new business registrations (per 1000 people ages 15$64)$ by $1 \%$ leads to a the rise in international trade (\% of GDP) by $0.64 \%$.

Table 5. The findings of research on the impact of logistics performance changes on international trade changes

\begin{tabular}{|l|c|c|c|c|c|}
\hline \multicolumn{5}{|c|}{ Fixed-effects, using 324 observations } \\
\hline & $\begin{array}{c}\text { Coeffi- } \\
\text { cient }\end{array}$ & $\begin{array}{c}\text { Std. } \\
\text { Error }\end{array}$ & t-ratio & p-value \\
\hline const & 1.52537 & 0.43608 & 3.498 & $0.0005^{* * *}$ \\
\hline d_LPI & 0.00251 & 4.23135 & 1.188 & 0.2361 \\
\hline d_GCF_pc & 0.02561 & 0.00037 & 6.889 & $0.0001^{* * *}$ \\
\hline d_NBD & 0.64402 & 0.33615 & 1.916 & $0.0564^{*}$ \\
\hline $\begin{array}{l}\text { Mean depend- } \\
\text { ent var }\end{array}$ & 1.502238 & $\begin{array}{l}\text { S.D. de- } \\
\text { pendent var }\end{array}$ & 7.8800 \\
\hline $\begin{array}{l}\text { Sum squared } \\
\text { resid }\end{array}$ & 14737.87 & $\begin{array}{l}\text { S.E. of re- } \\
\text { gression }\end{array}$ & 7.4295 \\
\hline $\begin{array}{l}\text { LSDV } \\
\text { R-squared }\end{array}$ & 0.3601 & $\begin{array}{l}\text { Within } \\
\text { R-squared }\end{array}$ & 0.2915 \\
\hline $\begin{array}{l}\text { LSDV } \\
\text { F(29,267) }\end{array}$ & 2.2752 & P-value(F) & 0.0004 \\
\hline Log-likelihood & -1001.24 & $\begin{array}{l}\text { Akaike } \\
\text { criterion }\end{array}$ & 2062 \\
\hline $\begin{array}{l}\text { Schwarz } \\
\text { criterion }\end{array}$ & 2173.281 & \multicolumn{2}{|l|}{$\begin{array}{l}\text { Hannan- } \\
\text { Quinn }\end{array}$} & 2107 \\
\hline Rho & \multicolumn{3}{|c|}{0.0770} & $\begin{array}{l}\text { Durbin- } \\
\text { Watson }\end{array}$ & 2.0144 \\
\hline $\begin{array}{l}\text { Joint test on named regressors - Test statistic: } \\
\text { F(3,267) = 19.494 with p-value = P(F(3, 267) > } \\
\text { 19.494) = 1.85244e-011 }\end{array}$ \\
\hline
\end{tabular}

The determination coefficient (R-Squared) shows that model variables explain the variation of international trade changes by $36 \%$. It means that the model does not cover other factors that influence international trade. It is one of the limitations of the study. Another shortcoming - the study is not taking into account the possible lagged LPI changes and their impact on international trade. It has to be noted that authors delivered lagged impact test for five years, but time period is too short for the reliable model, so it is not easy to interpret assessment results. They do not indicate a significant impact. The attention should also be paid to the fact that separate components of LPI can influence international trade differently, including different directions. Such refers to continuing study assumptions. It would be wise to investigate the impact of all logistic performance components on international trade.
Moreover, the impact of changes of logistics performance on international trade may be insignificant since effects may differ across countries. Puertas et al. (2014) divided EU countries into two groups, according to LPI. They found that countries characterized by relatively weak logistical situation gain more from logistics positive changes in terms of impact on export. All these countries (except Greece and Portugal) joined the EU in 2004 and beyond. Taking this fact into consideration, we made additional investigation using the same econometric model (Formula 1) for the 15 EU MS which, according to Puertas el al. (2014), could be indicated as countries with relatively poor logistics situation: Bulgaria, Croatia, Cyprus, Czech Republic, Estonia, Greece, Hungary, Latvia, Lithuania, Malta, Poland, Portugal, Romania, Slovakia, Slovenia.

Table 6. Findings of additional estimations for 15 countries

\begin{tabular}{|c|c|c|c|c|c|c|}
\hline \multicolumn{7}{|c|}{ Fixed-effects, using 180 observations } \\
\hline \multicolumn{7}{|c|}{ Dependent variable: 1_IT_gdp } \\
\hline & \multicolumn{2}{|c|}{ Coefficient } & \multicolumn{2}{|c|}{$\begin{array}{l}\text { Std. } \\
\text { Error }\end{array}$} & t-ratio & p-value \\
\hline const & \multicolumn{2}{|c|}{5.02094} & \multicolumn{2}{|c|}{0.31449} & 15.97 & $<0.0001^{* * * *}$ \\
\hline d_LPI & \multicolumn{2}{|c|}{0.46444} & \multicolumn{2}{|c|}{0.12307} & 3.77 & $0.0002 * * *$ \\
\hline d_GCF_pc & \multicolumn{2}{|c|}{-0.10514} & \multicolumn{2}{|c|}{0.03332} & -3.16 & $0.0019 * * *$ \\
\hline d_NBD & \multicolumn{2}{|c|}{0.06048} & \multicolumn{2}{|c|}{0.02681} & 2.256 & $0.0254 * * *$ \\
\hline \multicolumn{2}{|c|}{$\begin{array}{l}\text { Mean dependent } \\
\text { var }\end{array}$} & \multicolumn{2}{|c|}{4.7846} & \multicolumn{2}{|c|}{$\begin{array}{l}\text { S.D. depend- } \\
\text { ent var }\end{array}$} & 0.3996 \\
\hline \multicolumn{2}{|c|}{$\begin{array}{l}\text { Sum squared } \\
\text { resid }\end{array}$} & \multicolumn{2}{|c|}{1.5672} & \multicolumn{2}{|c|}{$\begin{array}{l}\text { S.E. of re- } \\
\text { gression }\end{array}$} & 0.0984 \\
\hline \multicolumn{2}{|l|}{$\begin{array}{l}\text { LSDV } \\
\text { R-squared }\end{array}$} & \multicolumn{2}{|c|}{0.9452} & \multicolumn{2}{|c|}{$\begin{array}{l}\text { Within } \\
\text { R-squared }\end{array}$} & 0.1737 \\
\hline \multicolumn{2}{|l|}{$\begin{array}{l}\text { LSDV } \\
\mathrm{F}(29,267)\end{array}$} & \multicolumn{2}{|c|}{164.2682} & \multicolumn{2}{|c|}{ P-value $(F)$} & $1.03 \mathrm{e}-92$ \\
\hline \multicolumn{2}{|c|}{ Log-likelihood } & \multicolumn{2}{|c|}{171.5197} & \multicolumn{2}{|c|}{$\begin{array}{l}\text { Akaike } \\
\text { criterion }\end{array}$} & -307 \\
\hline \multicolumn{2}{|c|}{$\begin{array}{l}\text { Schwarz criteri- } \\
\text { on }\end{array}$} & \multicolumn{2}{|c|}{-249} & \multicolumn{2}{|c|}{$\begin{array}{l}\text { Hannan- } \\
\text { Quinn }\end{array}$} & -284 \\
\hline \multicolumn{2}{|l|}{ rho } & \multicolumn{2}{|c|}{0.5915} & \multicolumn{2}{|c|}{$\begin{array}{l}\text { Durbin- } \\
\text { Watson }\end{array}$} & 1.7869 \\
\hline \multicolumn{7}{|c|}{$\begin{array}{l}\text { Joint test on named regressors }- \text { Test statistic: } \\
\mathrm{F}(3,162)=11.3527 \text { with } \text {-value }=\mathrm{P}(\mathrm{F}(3,162)> \\
11.3527)=8.47693 \mathrm{e}-007\end{array}$} \\
\hline
\end{tabular}

It should be noted that Puertas et al. (2014) do not include Malta and Croatia into the sample due to the lack of data. However, the data is available now; therefore, we extended the sample from 13 countries to 15 . Research results are presented in Table 6. 
The results of additional estimation show that countries characterised as countries with relatively poor logistic performance, have positive changes in logistic situation and positively and significantly influences international trade. The increase of LPI by 1-point leads to an increase in international trade (\% of GDP) by $0.46 \%$. These results are in line with the results of research by Puertas et al. (2014). But this research expand results of previous studies as well as contribute science in some way. The study proves that logistic performance is essential not only for export but also for import flows. Moreover, authors confirm the assumption that the impact of logistics performance on international trade is different across countries.

Also, it could be argued that the changes of logistic performance indirectly (through the intensification of trade flows) influences economic growth of new EU member states.

In general, countires that joined the EU in 2004 and beyond, including Greece and Portugal, have to target economic politics to the improvement of logistics performance.

\section{Conclusions}

The review of the literature shows the possible country contribution to LPI based on income level and allocated investments. Discussion on LPI is still ongoing among researchers who aim to define the size of weight to be assigned to the core elements of the index. Nevertheless, LPI created by by World bank in colloboraion with Turku School of Economics, University of Turku, is the most common indexes.

The excellent performance of logistics anlarges the volume of trade that also influences the size of distribution and production and stimulates further economic development.

The analysis of previous studies reveals that logistic performance can contribute to the growth of international trade. However, research on this issue is limited.

The analysis of international trade and logistics performance over 2007-2018 reveals that both the performance of logistic and the flows of international trade were growing in almost all EU countries. However, countries ranking according to international trade and LPI 2018 data has revealed that excellent logistic performance of the country does not necessarily associate with intensive international trade flows. It led to the assumption that logistic performance effects on international flows differ across countries.
The results of regression analysis confirm positive but statistically insignificant changes of logistic performance impact on international trade changes when we used an all sample of EU MS. International trade flows are more dependent on new business density. An increase in new business registrations (per 1000 people ages 15-64) by 1\% leads to a rise in international trade (\% of GDP) by $0.64 \%$.

But results of additional estimations revealed that in countries that joined the EU in 2004 and beyond, as well as in Greece and Portugal, LPI changes have a positive and significant impact on international trade. Those countries must target economic politics to logistic performance improvement to ensure economic growth due to more intensive international trade flows.

Our findings are in line with findings of previous researches. Still, they expand its results as well as contribute science since prove that logistic performance is essential not only for export but also for import flows and confirme the assumption that logistics performance impact on international trade differs across countries.

\section{Contribution}

Conceptualization, $\mathrm{AMS}$ and $\mathrm{AB}$; methodology, data collection and investigation, AMS; theoretical analysis, $\mathrm{AB}$; abstract and conclusions, AMS and $\mathrm{AB}$; writing - original draft preparation, AMS and AB. All authors contributed to the experiment design and have read and approved the final manuscript.

\section{Disclosure statement}

We declare that we do not have any competing financial, professional, or personal interests from other parties.

\section{References}

Abosedra, S., \& Tang, C. F. (2019). Are exports a reliable source of economic growth in MENA countries? New evidence from the rolling Granger causality method. Empirical Economics, 56(3), 831841. https://doi.org/10.1007/s00181-017-1374-7

Ali, G., \& Li, Z. (2018). Exports-led growth or growthled exports in the case of China and Pakistan: An empirical investigation from the ARDL and Granger causality approach. International Trade Journal, 32(3), 292-314. https://doi.org/10.1080/08853908.2017.1379449

Anderson, B., \& Villa, J. C. (2015). Transportation and trade across international borders. Research in 
Transportation Business and Management, 16, 13. https://doi.org/10.1016/j.rtbm.2015.08.005

Arvis, J. F., Ojala, R., Wiederer, Ch., Shepherd, B., Raj, A., Dairabayeva, K., \& Kiiski, T. (2018). Connecting to compete. Trade logistics in the global economy. Logistics performance infex and its indicators. World bank, Washington. https://doi.org/10.1596/29971

Awokuse, T. O. (2008). Trade openness and economic growth: is growth export-led or import-led? Applied Economics, 40(2), 161-173. https://doi.org/10.1080/00036840600749490

Banomyong, R., Cook, P., \& Kent, P. (2008). Formulating regional logistics development policy: The case of ASEAN. International Journal of Logistics Research and Applications, 11(5), 359-379. https://doi.org/10.1080/13675560802389114

Çemberci, M., Civelek, M. E., \& Canbolat, N. (2015). The moderator effect of global competitiveness index on dimensions of logistics performance index. Procedia-Social and Behavioral Sciences, 195, 15141524. https://doi.org/10.1016/j.sbspro.2015.06.453

Chow, H. K. H., Choy, K. L., Lee, W. B., \& Chan, F. T. S. (2005). Design of a knowledge based logistics strategy system. Expert Systems with Applications, 29(2), 272-290. https://doi.org/10.1016/j.eswa.2005.04.001

Civelek, M. E., Uca, N., \& Çemberci, M. (2015). The mediator effect of logistics performance index on the relation between global competitiveness index and gross domestic product. European Scientific Journal, 5, 8-19.

D’Aleo, V., \& Sergi, B. S. (2017). Does logistics influence economic growth? The European Experience. Management Decision, 55(8), 1613-1628. https://doi.org/10.1108/MD-10-2016-0670

Davidaviciene, V., \& Maciulyte-Sniukiene, A. (2019). The impact of international trade on EU member states performance. In Conference Proceedings "New Challenges of Economic and Business Development 2019”, (pp. 204-216). University of Latvia, Riga, Latvia.

Devlin, J., \& Yee, P. (2005). Trade logistics in developing countries: the case of the Middle East and North Africa. The World Economy, 28, 435-456. https://doi.org/10.1111/j.1467-9701.2005.00620.x

Gupta, S., Goh, M., Desouza, R., \& Garg, M. (2011). Assessing trade friendliness of logistics services in ASEAN. Asia Pacific Journal of Marketing and Logistics, 23(5), 773-792. https://doi.org/10.1108/13555851111183444

Hausman, W. H., Lee, H. L., \& Subramanian, U. (2005). Global logistics indicators, supply chain metrics, and bilateral trade patterns (Policy Research Working Paper No. 3773). World Bank. https://doi.org/10.1596/1813-9450-3773

Hausman, W. H., Lee, H. L., \& Subramanian, U. (2013). The impact of logistics performance on trade. Production and Operations Management, 22(2), 236-252.

https://doi.org/10.1111/j.1937-5956.2011.01312.x

Havenga, J. H. (2011). Trade facilitation through logistics performance: the enabling role of national government. Journal of Transport and Supply Chain Management, 5(1), 123-148. https://doi.org/10.4102/jtscm.v5i1.25

Havenga, J., Simpson, Z., \& Goedhals-Gerber, L. (2016). International trade logistics costs in South Africa: Informing the port reform agenda. Research in Transportation Business and Management, 22, 263-275.

https://doi.org/10.1016/j.rtbm.2016.08.006

Hoekman, B., \& Nicita, A. (2011). Trade policy, trade costs, and developing country trade. World Development, 39(12), 2069-2079.

https://doi.org/10.1016/j.worlddev.2011.05.013

Kabak, Ö., Ülengin, F., \& Ekici, Ş. Ö. (2018). Connecting logistics performance to export: A scenariobased approach. Research in Transportation Economics, 70, 69-82. https://doi.org/10.1016/j.retrec.2018.05.007

Lai, K. H., \& Wong, C. W. (2012). Green logistics management and performance: some empirical evidence from Chinese manufacturing exporters. Omega, 40(3), 267e282.

https://doi.org/10.1016/j.omega.2011.07.002

Lakshmanan, T. R., Subramanian, U., Anderson, W., \& Leautier, F. (2001). Integration of transport and trade facilitation. World Bank, Washington. https://doi.org/10.1596/0-8213-4884-1

Limao, N., \& Venables, A. J. (2001). Infrastructure, geographical disadvantage, transport costs and trade. World Bank Economic Review, 15(3), 451479. https://doi.org/10.1093/wber/15.3.451

Mahadevan, R., \& Suardi, S. (2008). A dynamic analysis of the impact of uncertainty on import- and/or exportled growth: The experience of Japan and the Asian Tigers. Japan and the World Economy, 20(2), 155174. https://doi.org/10.1016/j.japwor.2006.10.001

Mariano, E. B., Gobbo Jr, J. A., de Castro Camioto, F., \& do Nascimento Rebelatto, D. A. (2017). $\mathrm{CO}_{2}$ emissions and logistics performance: a composite index proposal. Journal of Cleaner Production, 163, 166178. https://doi.org/10.1016/j.jclepro.2016.05.084

Martí, L., Martín, J. C., \& Puertas, R. (2017). A DEAlogistics performance index. Journal of Applied Economics, 20(1), 169-192. https://doi.org/10.1016/S1514-0326(17)30008-9

Memedovic, O., Ojala, L., Rodrigue, J. P., \& Naula, T. (2008). Fuelling the global value chains: What role for logistics capabilities? International Journal of Technological Learning Innovation Development, 1(3), 353-374.

https://doi.org/10.1504/IJTLID.2008.019978

Ojala, L., \& Celebi, D. (2015, August 7-8). The World Bank's Logistics Performance Index (LPI) and 
drivers of logistics performance. in Proceeding of MAC-EMM Conference. Praha, Czech.

Palley, T. I. (2011). The rise and fall of export-led growth (Working Paper No. 675). Levy Economics Institute of Bard College. https://doi.org/10.2139/ssrn.1889167

Puertas, R., Martí, L., \& García, L. (2014). Logistics performance and export competitiveness: European experience. Empirica, 41(3), 467-480. https://doi.org/10.1007/s10663-013-9241-z

Rezaei, J., van Roekel, W. S., \& Tavasszy, L. (2018). Measuring the relative importance of the logistics performance index indicators using Best Worst Method. Transport Policy, 68, 158-169. https://doi.org/10.1016/j.tranpol.2018.05.007

Rodrigues, A. M., Bowersox, D. J., \& Calantone, R. J. (2005). Estimation of global and national logistics expenditures: 2002 data update. Journal of Business Logistics, 26(2), 1-16. https://doi.org/10.1002/j.2158-1592.2005.tb00202.x

Roy, V., Mitra, S. K., Chattopadhyay, M., \& Sahay, B. S. (2018). Facilitating the extraction of extended insights on logistics performance from the logistics performance index dataset: A two-stage methodological framework and its application. Research in Transportation Business and Management, 28, 23-32. https://doi.org/10.1016/j.rtbm.2017.10.001

Sharipbekova, K., \& Raimbekov, Z. (2018). Influence of logistics efficiency on economic growth of the CIS countries. European Research Studies Journal, 21(2), 678-690. https://doi.org/10.35808/ersj/1032

Tang, C. F., \& Abosedra, S. (2019). Logistics performance, export, and growth: Evidence from Asian economies. Research in Transportation Economies, 78, 1-9.

https://doi.org/10.1016/j.retrec.2019.100743

Tietje, O. (2005). Identification of a small reliable and efficient set of consistent scenarios. European Journal of Operational Research, 162, 418-432. https://doi.org/10.1016/j.ejor.2003.08.054

Wang, Y., Caron, F., Vanthienen, J., Huang, L., \& Guo, Y. (2014). Acquiring logistics process intelligence: Methodology and an application for a Chinese bulk port. Expert Systems with Applications, 4l(1), 195-209. https://doi.org/10.1016/j.eswa.2013.07.021

Wangel, J. (2011). Change by whom? Four ways of adding actors and governance in backcasting studies. Futures, 43, 880-889. https://doi.org/10.1016/j.futures.2011.06.012

World Bank. (2014). Trade and transport facilitation assessment: a practical toolkit for country implementation. Washington.

World Bank. (n.d.). Logistic performance index. https://data.worldbank.org/indicator/LP.LPI.OVRL .XQ

Yang, M. H., \& Wu, C. S. (2015). Revisit export and GDP nexus in China \& Taiwan: A rolling window Granger causality test. Theoretical and Applied Economics, 22(3), 75-92.

Zaman, K., \& Shamsuddin, S. (2017). Green logistics and national scale economic indicators: Evidence from a panel of selected European countries. Journal of Cleaner Production, 143, 51-63. https://doi.org/10.1016/j.jclepro.2016.12.150 